\title{
The Swedish Riksdag as Scrutiniser of the Principle of Subsidiarity
}

\author{
Anna Jonsson Cornell*
}

\begin{abstract}
Early Warning Mechanism - Principle of Subsidiarity - Lisbon Treaty - Protocol No. 2 on Proportionality and Subsidiarity - A theoretical definition of the Principle of Subsidiarity - The scope of the Principle of Subsidiarity - Scrutiny of the respect for the principle of subsidiarity - The role of national parliaments in the EU legislative procedure - The Swedish Riksdag - national constitutional law decentralised scrutiny - no selection mechanism - sectoral committees - reasoned opinions - the role of the Plenary - the Committee on the Constitution - method for scrutiny - the principle of proportionality - principle of conferral - legality European Public Prosecutor's Office - broad or narrow scrutiny - impact of the Early Warning Mechanism
\end{abstract}

\section{INTRODUCTION}

The Early Warning Mechanism has been the subject of many studies recently. Some of the main conclusions are that Early Warning Mechanism is a strait jacket, that it will not serve its purpose since the Commission does not take its duty to motivate seriously, that national parliaments are weak and disorganised in their scrutiny of EU matters and that they should focus on scrutinising their governments instead, that the design of the Mechanism provides weak incentives to engage, and that national parliaments do not adhere to the formal requirements of how reasoned opinions should be framed, to mention just a few examples. Moreover, the scope of the scrutiny of subsidiarity itself is debated: should it be narrow or broad? National parliaments themselves are critical towards the role they have been given by the Early Warning Mechanism and have presented ways of making their impact on the EU legislative procedure stronger. The Early Warning Mechanism proper and the role of national parliaments in the

*The author is very grateful for the valuable comments from Dr Hans Hegeland and the anonymous reviewers. 
EU legislative process are thus subject to both academic and policy debate. ${ }^{1}$ Several ideas on how to improve the position and influence of national parliaments within this context have been introduced. Thus far, none has provoked any real action from the Commission. Most of the ideas for improvement are focusing on how to either expand or remodel the role of national parliaments within the EU legislative process. Noteworthy, most of the suggested reforms take their starting point in the failure of the national parliaments to render correctly-framed reasoned opinions, their habit of misinterpreting the task assigned to them by the Early Warning Mechanism ${ }^{2}$, the lack of real impact on the EU legislature, and the risk of the Mechanism distracting parliaments from what they 'should do', i.e. develop new policies and exercise control of national governments. ${ }^{3}$ In light of this very fact, i.e. that national parliaments are stuck with a procedure not likely to change in the near future, the purpose of this case study is to add to the debate and analysis by shedding light on the problems encountered in one of the most active national parliaments within the Early Warning Mechanism, the Swedish Riksdag, and to suggest improvements to the Swedish scrutiny procedure. The implementation of the Mechanism in national constitutional orders depends on national constitutional traditions and regulatory framework. One of the main findings of this article is that the lack of a centralised approach to methodological issues in the Swedish scrutiny process makes the scrutiny process less focused and more inefficient, with the result that the subsidiarity argument does not reach its full potential. Sweden has opted for a decentralised system of subsidiarity scrutiny within the Early Warning Mechanism. The Swedish European Affairs Committee is not involved in the scrutiny and Sweden stands out in this regard. Instead, the Swedish Committee on the Constitution is given the task of observing general trends and providing a yearly report on the scrutiny by sectoral committees.

Sweden is often termed a particularly strong parliamentary democracy and part of what is sometimes referred to as the Nordic model. ${ }^{4}$ However, even within the

\footnotetext{
${ }^{1}$ This particular topic is being dealt with in A. Jonsson Cornell and M. Goldoni (eds.), National and Regional Parliaments in the EU-legislative Procedure post-Lisbon. The Impact of the Early Warning System (Hart 2016). See also D. Jančić, 'The Game of Cards: National Parliaments in the EU and the Future of the Early Warning Mechanism and the Political Dialogue', 52 CMLRev (2015) p. 939.

${ }^{2}$ See, for example, the special issue 'After Lisbon: National Parliaments in the EU', 38(2) West European Politics (2015).

${ }^{3}$ Jančić, supra n. 1.

${ }^{4}$ Scholars have pointed out important differences in how Nordic national parliaments have approached their post-Lisbon responsibilities, focusing on the scrutiny of the principle of subsidiarity. I. Cooper, 'The Nordic Parliaments and the EU', in C. Howard Gron et al. (eds.), Still the other European Community? The Nordic Countries and the European Union (Routledge 2015) p. 1, I. Cooper, 'The Subsidiarity Early Warning Mechanism: Three Questions and a Typology', and A. Jonsson Cornell, 'Similar but Different: Comparing the Scrutiny of the Principle of Subsidiarity in Sweden, Denmark and Finland', both in Jonsson Cornell and Goldoni, supra n. 1.
} 
Nordic context Sweden stands out for several reasons. The most obvious reason is the magnitude of reasoned opinions delivered by the Swedish Riksdag since 2010. Between the entry into force of the Lisbon Treaty and the end of 2014 the Riksdag reviewed a total of 501 proposals and submitted 45 reasoned opinions as a result of scrutiny of the principle of subsidiarity. ${ }^{5}$ The Swedish case is of interest taking into consideration the high number of reasoned opinions delivered thus far, the fact that scrutiny is delegated to sectoral committees, and the yearly follow-up reports and analysis provided by the Committee on the Constitution. It has been argued that the low number of reasoned opinions in general could be explained by the practical and political shortcomings of the Early Warning Mechanism, for example the eight-week time frame and the fact that it is unlikely, so the argument goes, that a majority in a national parliament will vote against its party leadership in government. ${ }^{6}$ The latter argument applies only to majority governments; which is why Sweden might be an interesting case, having been run by a centre-right minority government between 2010 and 2014 .

This article adds to a number of case studies on the implementation of the Early Warning Mechanism into national constitutional orders, ${ }^{7}$ and provides a deeper analysis of the Swedish Riksdag. It differs from earlier research on the Mechanism and the scrutiny of the principle of subsidiarity in that it focuses on one particular country and hence it does not aim to contribute to what thus far has been the dominating research questions, i.e. whether national parliaments collectively are apt to use the Early Warning Mechanism, whether national parliaments are victims of integration, losers or latecomers, or gatekeepers of EU integration, whether the Mechanism empowers national parliaments to become new actors in the EU arena or whether it is just window dressing. ${ }^{8}$ Rather it adopts a national constitutional law perspective and aims to trace the impact of the Early Warning Mechanism on one particular constitutional order, focusing especially on the scope of the subsidiarity review exercised by the Swedish Riksdag and the role played by the Committee on the Constitution. ${ }^{9}$ In Sweden the European Affairs

${ }^{5}$ 2014/15:KU5, p. 21, 39, 2015/16:KU5.

${ }^{6}$ O. Rozenberg and C. Hefftler, 'Introduction', in C. Hefftler et al. (eds.), The Palgrave Handbook of National Parliaments and the European Union (Palgrave Macmillan 2015) p. 22.

${ }^{7}$ For example P. Kiiver, The Early Warning Mechanism System for the Principle of Subsidiarity. Constitutional Theory and Empirical Reality (Routledge 2012), P. Popelier and W. Vandenbruwaene, 'The Subsidiarity Mechanism as a Tool for Inter-Level Dialogue in Belgium: On Regional Blindness and Cooperative Flaws', 7 EuConst (2011) p. 204, L. Besselink and B. van Mourik, 'The Parliamentary legitimacy of the European Union: The Role of the States General within the European Union', 8(1) Utrecht Law Review (2012) p. 28, and Jonsson Cornell, supra n. 4.

${ }^{8}$ Rozenberg, supra n. 6, p. 17, 21. See also D. Jančić, 'The Barroso Initiative: Window Dressing or Democracy Boost?', 8(1) Utrecht Law Review (2012) p. 78.

${ }^{9}$ For the latest contribution on national parliaments in general, see Hefftler et al., supra n. 6. In Jonsson Cornell and Goldoni, supra n. 1, case studies focusing on the Early Warning Mechanism 
Committee is not the main actor within the Early Warning Mechanism, which is the case in for example Denmark. ${ }^{10}$

The article is structured as follows: It starts with an account of the theoretical and empirical state of the art concerning the scope of subsidiarity review within the Early Warning Mechanism. This part highlights disagreements between scholars as to the scope of the scrutiny of the principle of subsidiarity by national parliaments within the Early Warning Mechanism. It then proceeds with an analysis of the procedural aspects of the scrutiny of subsidiarity within the Swedish constitutional system focusing on the Mechanism. (Clearly, the Political Dialogue is of importance for all national parliaments' participation in the EU legislative process. ${ }^{11}$ Focus in this article will, however, be only on the scrutiny of the principle of subsidiarity within the Early Warning Mechanism.) Thereafter the question of how the Swedish Riksdag has understood the subsidiarity review will be answered, to be followed by an analysis of the style and content of the reasoned opinions issued by the Riksdag. The manner in which the Riksdag deals with the issue of proportionality in this context will be especially highlighted. The Committee on the Constitution monitors this activity and produces a yearly report. The role of the Committee will be critically assessed. The empirical data used is primarily official Swedish documents prepared by the Riksdag, including reasoned opinions, the yearly reports from the Committee on the Constitution, and travaux preparatoire.

\section{THE SCOPE OF THE SCRUTINY OF THE PRINCIPLE OF SUBSIDIARITY}

The Early Warning Mechanism has been dealt with extensively in both legal and political science scholarship. One of the main issues concerns the nature of the Mechanism: is it and/or should it be primarily legal or political ${ }^{12}$ The Early Warning Mechanism has also been criticised for its procedural weaknesses, especially its short time frame and the fact that political actors, national parliaments, are to assess legal matters of high constitutional dignity. One question of great importance in this context concerns the scope of the scrutiny exercised by national parliaments: should national parliaments only review at what level (EU or MS) the measure should be taken (the narrow (legal) review), or should they also consider the principle of proportionality, whether the correct legal basis is applied,

proper in inter alia Italy, Belgium, France, the UK, Poland and the Czech Republic, Germany and Austria Sweden, Denmark and Finland are presented.

${ }^{10}$ For a comparative analysis see Jonsson Cornell, supra n. 4.

${ }^{11}$ Jančić, supra n. 8.

${ }^{12}$ See, for example, M. Goldoni, 'The Early Warning System and the Monti II Regulation: the Case for a Political Interpretation', 10 EuConst (2014) p. 90, and Cooper, supra n. 4. 
and the substance of the proposal (the broad review)? ${ }^{13}$ There is no consensus, neither among national parliaments nor among scholars concerning this particular question. Meanwhile, the interpretation and application of the principle of subsidiarity is likely to have, and already have had, impact on the EU legislative process. ${ }^{14}$

The scope of the review is necessarily linked to the purpose of the Early Warning Mechanism. Since there is no consensus as to the purpose there is obviously no consensus regarding the scope of the review. There are different approaches to this very question; they can be normative or empirical. ${ }^{15} \mathrm{~A}$ normative approach requires one to define the end game of the Early Warning Mechanism, if possible. Is it, for example, to strengthen representative national democracy and politics? Or to increase the legitimacy of the EU integrationist agenda? Or both? ${ }^{16}$ An empirical approach could be what Kiiver has engaged in, i.e. to define subsidiarity by adopting a bottom-up approach. ${ }^{17}$ In addition, different subsidiarity tests are suggested when it comes to the scope of the review and what it should be. One could argue that these tests are defined within the context of the end game of the Early Warning Mechanism. For example, Fabbrini and Granat argue for a narrow review of subsidiarity and suggest a test taking both the material and procedural aspects of the principle of subsidiarity into account. The material aspect includes the national insufficiency test and the comparative efficiency test. The procedural aspect relates to the motivation of a legislative proposal by the EU legislator. The latter is instrumental to the material aspects of the review. ${ }^{18}$ They argue that the scrutiny should focus 'exclusively to the control of the principle of subsidiarity, and leave aside considerations of the legal basis, proportionality or political merits of an EU legislative proposal ${ }^{19}$ based on a textual, functional and structural interpretation of Protocol No. 2.

${ }^{13}$ See for example F. Fabbrini and K. Granat, "Yellow Card but No Foul": The Role of the National Parliaments Under the Subsidiarity Protocol and the Commission Proposal For an EU Regulation on the Right to Strike', 50 CMLRev (2013) p. 115 at p. 120-125. The authors argue for a narrow review based on textual, structural and functional arguments. See also Jančić, supra n. 1 at p. 974, who calls for an expansion of the scope of the Early Warning Mechanism.

${ }^{14}$ In the case of the Monti II proposal the Commission withdrew its proposal due to a yellow card, even though the Commission insisted that there had been no violation of the principle of subsidiarity. A yellow card was issued concerning the EPPO-proposal on 28 October 2013.

${ }^{15}$ For the purpose of this article, empirical refers to the way in which national parliaments define and review subsidiarity.

${ }^{16}$ For a take on the EU point of view see Jančić, supra n. 1 at p. 944.

${ }^{17}$ Kiiver, supra n. 7, p. $96 \mathrm{ff}$.

${ }^{18}$ Fabbrini, supra n. 13, at p. 124-125. The authors build on R. Schütze, From Dual to Cooperative Federalism (Oxford University Press 2009) p. 250. The authors also argue for the 'cross-border activity' test, as put forward by Advocate General Maduro in ECJ 10 June 2010, Case C-58/08, Vodafone $\mathrm{v}$ Secretary of State for Business, Enterprise and Regulatory Reform, Opinion of A.G. Maduro.

${ }^{19}$ Fabbrini, supra n. 13, p. 121. 
The problem with the procedural aspect of the review, of course, is that the Commission does not clearly enough motivate its subsidiarity assessments. This criticism is frequently put forward by national parliaments. ${ }^{20}$ The Commission's disregard for this criticism is best illustrated by its response to the yellow card on the European Public Prosecutor's Office. In its response to the national parliaments it relied on the European Court of Justice's decision in Germany $v$ Parliament and Council ${ }^{21}$ stating that 'the Court accepted an implicit and rather limited reasoning as sufficient to justify compliance with the principle of subsidiarity. ${ }^{, 22}$ Moreover, it is the Commission itself that will decide when its obligation to motivate according to Article 296(2) TFEU is fulfilled. Kiiver's argument in relation to the Commission's (lack of) subsidiarity assessments still holds. He argues that an inadequate justification means a breach of subsidiarity in itself and for the following reasons: First, there are formal obligations on the Commission to justify why a draft is in congruence with the principle of subsidiarity, Articles 5 and 296 TEU, in combination with Protocol No 2. Second, national parliaments and the European Court of Justice cannot be required to provide better subsidiarity arguments afterwards only to detect breaches. Therefore an inadequate justification should be considered a breach of the principle of subsidiarity. ${ }^{23}$ Moreover, it could be argued that the decision of the European Court of Justice in Germany v Parliament and Council did not focus on motivations within the Early Warning Mechanism and that the Commission therefore should have focused on the purpose of the Mechanism and its obligations according to the TEU, instead of case law from before the Lisbon Treaty and the Protocol entered into force. ${ }^{24}$

Fabbrini and Granat offer a top-down interpretation of the scope of the subsidiarity review based on a textual, functional and structural interpretation of Protocol No. 2 that shows a clear bias toward the EU legislator, and hence an EU integrationist agenda. ${ }^{25}$ Goldoni calls this approach 'a strictly formalist reading ${ }^{26}$ and then proceeds with a contextual and teleological interpretation, taking his starting point in Articles 10 and 4(2) TEU. A contextual and teleological reading of these articles allows for a broader definition of the review. Goldoni argues that if understood in a thin fashion as simply a question of which level should decide on what, subsidiarity is reduced to a technical exercise of

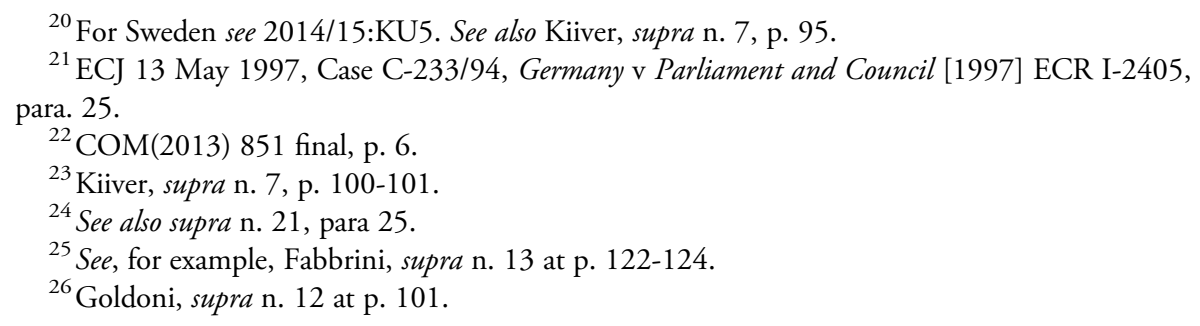


competence review and it betrays, by institutional design, a pro-European centripetal prejudice. ${ }^{, 27}$ By allowing for a broader and political interpretation of subsidiarity review member states will be allowed yet another channel for voicing concerns about their national models and thereby, potentially, reducing their reluctance. This approach would, according to Goldoni, allow national parliaments to become the main guarantors of national constitutional culture when all other channels are closed. ${ }^{28}$ This approach would allow the Early Warning Mechanism to become an arena for voicing national particularities worthy of protection according to national parliaments. By so doing the communicative sphere for conflicts between the social and political is upheld by the body most suitable for this, i.e. national representative bodies. ${ }^{29}$ In conclusion, according to Goldoni the Early Warning Mechanism could be viewed as a political instrument to 'contain unwarranted expansion of EU competences' and 'avoid negative effects of EU competences upon national constitutions essentials' ${ }^{30}$ Goldoni could be read as offering a bottom-up approach to the purpose of the Early Warning Mechanism, with the main purpose to safeguard a representative political space on the national level and national constitutional identities, but he does not offer any test or model for how national parliaments should engage in this more broad scope of subsidiarity review. In a more recent article Jančić makes an argument for a broad scope of the review to include an evaluation of the principle of conferral and the substance of the legislative proposal. By so doing, the legitimacy of the EU legislative process could be improved and the democratic deficit alleviated. ${ }^{31}$ Both Goldoni and Jančić agree that national parliaments, in order to act as genuine gatekeepers, need to address the substance of EU policies that deepens EU integration. In contrast to the top-down and narrow perspective on the scope of the principle of subsidiarity suggested by Fabbrini and Granat, Kiiver suggests a bottom-up approach based on empirical findings. ${ }^{32}$ By approaching the problem bottom-up, and based on the analysis of the opinions of national parliaments, Kiiver reaches the conclusion that 'subsidiarity should be understood very broadly', and include competence ${ }^{33}$ and proportionality, but exclude substance. Concerning proportionality, the 'victim is the intactness of national competence'. ${ }^{34}$ Kiiver's definition of the scope of the review is thus narrower than the approach suggested by Goldoni

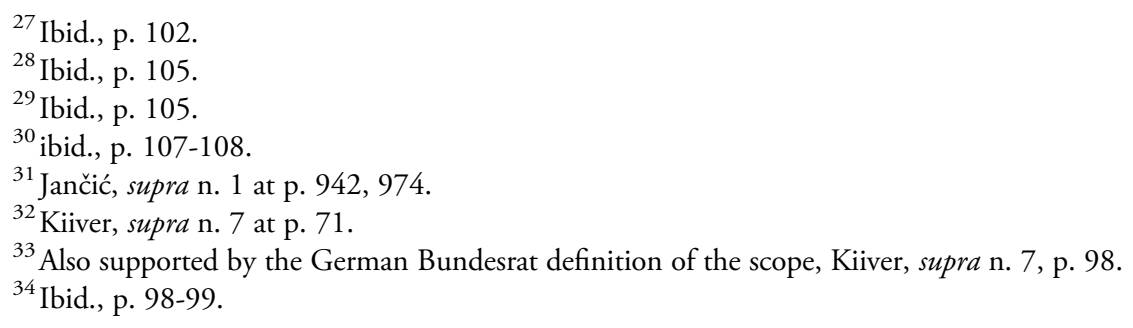


and Jančić ${ }^{35}$ respectively, although still within the broad review category. Kiiver, Goldoni and Jančić take their starting point in the member states' perspective on the scope of the scrutiny of subsidiarity trying to find ways to define the scope so that it is of relevance for national parliaments and the context in which they are acting. As we shall see, the Swedish model for scrutiny is close to both Kiiver's and Goldoni's approach to the scope of the review in the sense that both legality and proprtionality are taken into consideration by the Riksdag.

Yet another problematic area in establishing the scope of the review of the principle of subsidiarity is in terms of centralisation versus decentralisation processes and the division of powers between the EU and its member states. In this particular context the main question is whether the review should mainly support effective integration at the EU level, or whether it primarily aims to guard decentralisation and hence member states' powers? In a report commissioned by the Swedish Committee on the Constitution the authors support the latter understanding of the principle of subsidiarity, based on a contextual analysis, taking into account the Treaties and the fact that the burden of proof concerning EU regulations rests on the EU. ${ }^{36}$ For example, should the Commission contest national rules transposing a Directive, it has the burden of proof, when exercising its supervisory power, of establishing whether the instruments used by the Member State are contrary to Community law. ${ }^{37}$ My reading of Kiiver and Goldoni is that they too would favour the latter, while Fabbrini and Granat would adopt the EU integrationist approach.

In a recent article Ian Cooper has developed a typology of approaches to the Early Warning Mechanism. He argues that instead of there being merely two approaches to the Mechanism (legal or political), there are three. One of them is legal and the other two are political: (1) legal rule-following (legal); (2) political bargaining (political); and (3) political arguing (political). Each of these three approaches has its own understanding of subsidiarity. In the first approach subsidiarity is a legal rule with a narrow definition, with the effect that it will only be applied rarely, and all non-legal arguments should be communicated through the Political Dialogue. Cooper refers to the review exercised by the Finnish Eduskunta as an example. In the second approach subsidiarity is an elastic concept

${ }^{35}$ Jančić, supra n. 1 at p. 974.

${ }^{36}$ J. Hettne et al., Subsidiaritet I EU efter Lissabon, 2013/14:RFR 10, p. 15. Concerning the burden of proof on the Commission in this regard, see ECJ 23 September 2009, Case T-263/07, Republic of Estonia $\mathrm{v}$ Commission, para. 52, on the transposition of a Directive into national law. The Court stated '... in a field such as that of the environment, which is governed by Articles 174 EC to 176 EC, where the Community and the Member States share competence, the Community, that is to say the Commission in the present case, has the burden of proving to what extent the powers of the Member State and, therefore, its freedom of action, are limited ....'

${ }^{37}$ ECJ 23 September 2009, Case T-263/07, Republic of Estonia v Commission, para. 51. 
and hence it allows for a broad (political) scrutiny within the Early Warning Mechanism. Subsidiarity arguments are made mainly for political reasons and the Mechanism is applied since it provides more leverage than the Political Dialogue. Political expediency is of outmost concern. The Danish Folketing is referred to as an example. In the third category subsidiarity is ambiguous: 'vague but not meaningless'. For the scope of the subsidiarity review this means that matters of political expediency should be excluded, but political arguments could still be included within the Early Warning Mechanism. According to Cooper the Swedish Riksdag exemplifies the Political Arguing approach. ${ }^{38}$ In the following a case study of the implementation of the Early Warning Mechanism in the Swedish constitutional system will be provided. Thereafter the Swedish review of subsidiarity will be discussed and analysed, taking into consideration the debate on the scope of the review.

\section{The Swedish case}

\section{Institutional and procedural aspects}

In this second part of the article a Swedish case study will be conducted focusing on the implementation of the Early Warning Mechanism into the Swedish constitutional system, especially the scope of the scrutiny of the principle of subsidiarity.

The powers given to national parliaments as a result of the Lisbon Treaty and the Protocol have been enacted into Swedish law by changes to riksdagsordningen ${ }^{39}$ [the Riksdag Act]. Until 1974, riksdagsordningen held the status of a constitution. Since then it is to be found between the constitution and ordinary statutes $(\mathrm{lag})$ in the hierarchy of legal norms. The Riksdag's dealings with EU matters are regulated in Chapters 7 and 9 of the riksdagsordningen. According to riksdagsordningen 9:23, the Riksdag is to obtain written information from the EU in accordance with the Treaties and relevant protocols. According to regeringsformen 10:10 [the Instruction of Government] and riksdagsordningen 9:21, the Government is to keep the Riksdag continuously informed and updated on current EU affairs.

From a procedural point of view there is a clear distinction between the Political Dialogue and the Early Warning Mechanism. The Political Dialogue is regulated in riksdagsordningen 9:20 (1) and 9:23. Since the sectoral committees deal with these documents at a much earlier point in time compared to the Mechanism, matters of substance are better scrutinised and debated. Within the

\footnotetext{
${ }^{38}$ Cooper, supra n. 4.

${ }^{39}$ The Riksdag Act was changed in 2014, Riksdagsordning (2014:801). The new law entered into force on 1 September 2014.
} 
context of the Early Warning Mechanism, riksdagsordningen 9:20 (2) is applicable. This means that the substance and material facts of the draft should not be scrutinised (which does not mean that it is not). At this point the focus should be solely on the principle of subsidiarity and the question of at what level the measure should be taken, according to statements by the Swedish Committee on the Constitution. ${ }^{40}$ This has been identified as a weakness and changes have been suggested that would allow for the Riksdag to comment on the substance of a proposal when assessing its congruence with the principle of subsidiarity. ${ }^{41}$ However, to date no changes have been made to the riksdagsordningen to accomplish this. More importantly, the Swedish Riksdag is not allowed to communicate directly with the EU legislator outside of the Early Warning Mechanism procedure, due to a lack of legal basis in Swedish law. Thus, as the law currently stands, all communication within the Political Dialogue should go through the Swedish Government. ${ }^{42}$

The scrutiny of subsidiarity within the Early Warning Mechanism is decentralised in the sense that sectoral committees conduct the review. A general observation is that as a result of Sweden entering the EU, sectoral committees have gained in influence. In 1997, the riksdagsordningen imposed an obligation on sectoral committees to monitor EU activities and since 2007 the government has been obliged to deliberate with sectoral committees on EU affairs, riksdagsordningen 7:12 (1). Hegeland has argued that the power to have deliberations with the Government, as well as monitoring and producing reports on EU matters at an early stage of the process, has had an important impact on the role of sectoral committees in the scrutiny of the principle of subsidiarity. ${ }^{43}$

According to riksdagsordningen 9:20 (2), it is the Riksdag that shall control whether EU legislative proposals are in congruence with the principle of subsidiarity. The Swedish model is that the relevant sectoral parliamentary committee scrutinises proposals upon referral from the Chamber. All proposals are scrutinised, with no exceptions. ${ }^{44}$ This has provoked a debate between some sectoral committees and the Committee on the Constitution, leaving the latter to conclude that there are no formal requirements as to how sectoral committees should handle the scrutiny procedure as regards this particular question. Should a committee want to make the process more efficient by, for example, laying down a summarised procedure for drafts with no obvious subsidiarity concern, that is

\footnotetext{
${ }^{40}$ 2009/10:KU2 Tillämpning av Lissabonfördraget i riksdagen, p. 13.

${ }^{41}$ Hettne, supra n. 36, p. 43. See also 2008/09:RS4 Tillämpningen av Lissabonfördraget i riksdagen, p. 52.

${ }^{42}$ 2012/13:KU15. As a result of an e contrario reading of riksdagsordningen 11:21 2, 3 .

${ }^{43}$ H. Hegeland, 'The Swedish Parliament and EU Affairs: From Reluctant Player to Europeanized Actor', in Hefftler et al., supra n. 6, p. 425 at p. 428, 432.

${ }^{44}$ Hettne, supra n. 36, p. 45, 2013/14:KU5, p. 16.
} 
permissible and within the framework of the rules for scrutiny. ${ }^{45}$ The Chamber, with the assistance of the secretariat for EU affairs within the Riksdag Administration, distributes the incoming drafts to the sectoral committee in question. ${ }^{46}$ The scrutiny can be partial, meaning that both the whole proposal and parts of it can be considered to be in violation of the principle of subsidiarity.

If asked by a sectoral committee the Government is obliged to provide its assessment of subsidiarity concerning the draft in question within two weeks from the day the committee asked, riksdagsordningen 10:10 (2). Committees are not, however, obliged to consult the Government. ${ }^{47}$ This does not, strictly speaking, mean that the Government will provide an assessment, as was the case concerning the proposal on establishing a European Public Prosecutor's Office. In this case the Committee on Justice asked the Government to share its assessment, which it did not do even though the two-week deadline was extended. Clearly, this did have an impact on the scrutiny by the sectoral committee. ${ }^{48}$ As a result of the Government not fulfilling its obligations according to the riksdagsordningen a complaint was filed with the Committee on the Constitution within the framework of the Committee's constitutional control of the Government and its ministers, focusing on ministers' performance of their official duties and the handling of government business, regeringsformen 13:1. The Committee on the Constitution reached the conclusion that the Government had failed to meet its obligation under the riksdagsordningen and that it therefore could not avoid criticism. ${ }^{49}$

Sectoral committees can ask for other committees' assessment, including the Committee on the Constitution, riksdagsordningen 10:3 (2) - in the latter case, primarily concerning the interpretation of the principle of subsidiarity. ${ }^{50}$ If a committee finds a disregard for the principle of subsidiarity it delivers a statement to the Chamber to that effect, suggesting that the Riksdag send a reasoned opinion to the presidents of the European Parliament, Council and Commission. The Chamber will decide on the matter with a simple majority. Should the Chamber decide to send a reasoned opinion such a decision will be executed by a written statement, riksdagsordningen 11:21 (2). The Swedish regulation provides for a minority protection; if at least five committee members so require, a reasoned opinion shall be delivered to the Chamber. If the proposal is not considered to

${ }^{45}$ 2014/15:KU5, p. 17.

${ }^{46}$ Each of the sectoral committees has its own secretariat that assists in the further preparation. Supra n. 43, at p. 431.

${ }^{47}$ 2014/15:KU5, p. 40.

${ }^{48}$ 2013/14:JuU13, 2013/14:KU5, 2014/15:JuU2y.

${ }^{49}$ 2013/14:KU20, p. 18-21. There is no sanction mechanism involved. The only tool available is a vote of no-confidence in the Government, which is, at least in this context, a rather blunt tool.

${ }^{50}$ 2009/10:KU2, p. 14. 
violate the principle of subsidiarity it will suffice to submit an extract from the minutes to the Chamber, riksdagsordningen 10:3 (3).

\section{The Role of the Committee on the Constitution}

The Committee on the Constitution has the overall responsibility for monitoring and evaluating the scrutiny of the principle of subsidiarity by the sectoral committees, and reporting back to the Chamber. This is done once a year when the Committee submits a report to the Riksdag, riksdagsordningen 7:8 (2). ${ }^{51}$ The yearly report is structured according to the two main tasks of the Committee. The first task is to account for the number of reasoned opinions dealt with by the Riksdag and the method applied by sectoral committees (the formal aspect). ${ }^{52}$ When completing this task the Committee accounts for all proposals subject to review by the Riksdag, including their legal basis, categorised according to policy areas. ${ }^{53}$ This method, it is argued, allows the Riksdag to observe trends in the EU law-making process. Moreover, the Riksdag has designated the Committee on the Constitution as responsible for providing a 'helicopter perspective' on subsidiarity review, meaning that it is expected to study and analyse trends from the scrutiny processes in the sectoral committees. ${ }^{54}$ This is the second main task of the Committee. The Committee has interpreted this as requiring it to analyse the accumulated outcome of subsidiarity reviews by the sectoral committees on the division of powers between the EU and its Member States in order to avoid creeping violations of subsidiarity. In so doing the Committee focuses on different policy areas. The aim is that the Committee in the long run should be able to assess the impact on the division of competences between the EU and its Member States within the area of shared competence. In addition, the Committee is responsible for ensuring that the accumulated effect of decisions that a measure is not in violation with the principle of subsidiarity, will not risk coming to close to a violation, or unduly limit the space for national measures. ${ }^{55}$ One could argue that this very task is set to discover creeping competence overstretch by the EU and that it will allow the Riksdag to protect the interest of Sweden as a Member State against an overactive EU. Still, the Committee on the Constitution has clearly

${ }^{51}$ In October 2015 the Committee on the Constitution submitted five reports to the Riksdag, 2010/11:KU18, 2011/12:KU4, 2012/13:KU8, 2013/14:KU5, 2014/15:KU5 dealing with the years 2009-2013. The two first reports provided systematic analysis of all the review cases, while the final three focus more on the outcome of the review. Attention is also paid to weaknesses in the Commission's assessment of subsidiarity.

52 2014/15:KU5, p. 8.

${ }^{53}$ See, for example, 2014/15:KU5, p. 175.

${ }^{54}$ 2008/09:RS4 Tillämpningen av Lissabonfördraget i riksdagen, p. 53.

${ }^{55}$ 2013/14:KU5, p. 8-9. 
stated that it will not review the scrutiny made by sectoral committees in individual cases. ${ }^{56}$

We will start with the first main task of the Committee on the Constitution. The yearly reports provide a complete compilation of the number of subsidiarity checks by the Riksdag and statistics comparing this with earlier years, hence identifying changes over time. Initially, it was stated that these reports should also focus on methods used by the committees when scrutinising. However, in the 2013, 2014 and 2015 reports the Committee stated that it wished to focus more on the outcome of the EU legislative procedure in cases where reasoned opinions have been submitted, ${ }^{57}$ leaving the analysis of the methods applied by the sectoral committees somewhat behind. Thus, there is no overall assessment and analysis made by the Committee concerning the method actually applied by the sectoral committees.

In the process of completing its yearly report the Committee on the Constitution lets the other committees put forward their view of the formal procedure. In the 2013 report the Committee on Justice forwarded criticism as to the motivations provided by the Commission concerning subsidiarity and the goal to be achieved, on the one hand, and the weak reasoning from the Swedish Government concerning their stance on subsidiarity, on the other. It also called for a centralised and formalised procedure establishing an impact assessment concerning the subsidiarity review made by the Chamber. ${ }^{58}$ As a result, in its report from 2013 the Committee on the Constitution called for a centralised mechanism within the Riksdag that would assist in keeping track of the effects of reasoned opinions on the EU legislative procedure once they have been submitted to the EU. This applied only to statistics and facts concerning the outcome of the proposal, which at that point was the responsibility of the committees. As a result the EU coordination function within the Riksdag Administration has taken upon itself the task of keeping the sectoral committees informed when drafts they have submitted reasoned opinion upon are being approved by the EU legislator. ${ }^{59}$ This is important, due to the possibility of invoking a case before the European Court of Justice in accordance with Article 263 TFEU and Article 8 Protocol No 2. The time aspect is of the essence, since a case must be initiated within two months from the adoption of the legislative act. One of the main points in the report from 2014 was based on the fact that the Riksdag submitted 10 reasoned opinions in 2013, but the European Commission only reported receiving nine reasoned opinions from the Riksdag. As a result, the Committee underlined the importance of clearly

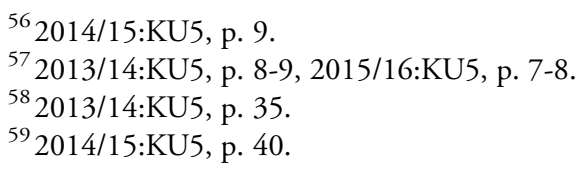


stating that a draft violates the principle of subsidiarity, in order that it be considered a reasoned opinion. We will return to this particular case below as a case in point in the argument for a more active Committee on the Constitution.

As regards the second main task of the Committee on the Constitution, the sectoral committees are generally asked to assess the overall impact of EU measures on their policy areas. Most of them have answered that it is too early to draw any conclusions due to the fact that the EU has not yet adopted most proposals. ${ }^{60}$ This underlines and adds yet another dimension to the necessity of effective follow-up mechanisms by the Riksdag. To give some examples of how the committees argue; the Committee on Finance stresses that there is an ongoing and intense development within the $\mathrm{EU}$ to strengthen economic control and regulation within the financial area. Subsequent to the financial crisis the number of EU legislative proposals has increased and hence provides greater influence for the EU within this policy area. ${ }^{61}$ An interesting observation in this context, and of great relevance for the space left for member states to act, is that the EU increasingly proposes regulations rather than directives, which diminishes member states' leeway in the implementation process and makes it more difficult to take national constitutional essentials into consideration when implementing. ${ }^{62}$ In its comment to the 2013 report the Committee on Justice concluded that the majority of proposals reviewed by the Committee on Justice dealt with criminal law cooperation and that this cooperation does mean that national competences are being transferred to the EU level, thus limiting the national competence. It emphasised, however, that most measures take the form of directives, hence making it possible for member states to take national specifics into consideration when implementing. ${ }^{63}$ In the 2014 report the Committee on the Constitution explicitly referred to the European Public Prosecutor's Office procedure, stating that it is of considerable importance that the Commission pays due attention to the principle of subsidiarity and proportionality taking into consideration that this draft did meet the threshold for the yellow card. ${ }^{64}$ In the 2014 report the Committee on the Constitution identified a problem related to the fact that negotiations on drafts are started before the deadline for the scrutiny of subsidiarity by national parliament has run out. The Committee underlined that such actions might undermine the scrutiny rights of national parliaments. ${ }^{65}$ The 2015 report added nothing new in this regard.

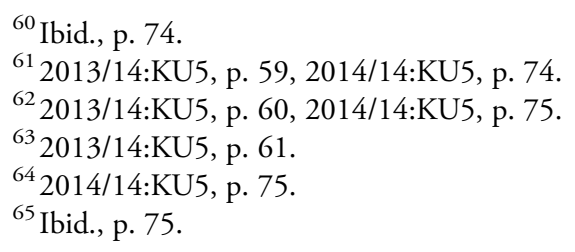




\section{The Swedish two-step method of scrutiny: is it offering clear guidance to the committees?}

The Swedish Riksdag, through the Committee on the Constitution, has recommended that its sectoral committees apply a two-step method when assessing whether a proposal is in congruence with the principle of subsidiarity. ${ }^{66}$ The first question to be asked is whether it is possible to achieve the goals through national measures? If the answer to this question is no, the measure should be taken at the EU level. If the answer is yes, the committee shall proceed by asking if measures at the EU level would be even better. If the answer to both questions is yes, there is no violation of the principle of subsidiarity. When considering the second question, the Riksdag recommends that the committees take the following into account: any trans-border effects; whether measures by Member States would violate the Treaties or harm Member States' interests; and whether measures at the EU level would bring clear advantages in terms of the effect of the proposed measure. Committees are also advised to seek guidance in the pre-Lisbon documents on the principle of subsidiarity. ${ }^{67}$ However, the parliamentary report on how to integrate the scrutiny of the principle of subsidiarity by national parliaments into Swedish law stated clearly that an assessment of the legality of the proposed measure, taking the principle of conferred powers into account, constitutes an obvious starting point for the scrutiny. Once legality (correct legal basis) has been established, the substance of the matter is not to be considered. ${ }^{68}$ The need to establish legality has been contested by the Committee on the Constitution in an opinion on one particular proposal, therefore the situation might be deemed unclear due to contradictionary statements in official documents. ${ }^{69}$ As I have argued elsewhere, the legality test is necessary for the subsidiarity test and therefore it should be explicitly added to the Swedish subsidiarity test. ${ }^{70}$ Hettne et al. subscribes to this and adds that should the result of the legality test show that there is no overstepping of competence on behalf of the EU, the result of this particular test does not need to be included in the reasoned opinion. ${ }^{71}$

In a report to the Riksdag, Hettne et al. puts forward a relevant and interesting critique of the subsidiarity test recommended by the Committee on the Constitution based on the following: The first step in the test recommended by

${ }^{66}$ 2013/14:KU5, p. 13-14.

${ }^{67}$ 2008/09:RS4 Tillämpningen av Lissabonfördraget i riksdagen, p. 52.

${ }^{68} \mathrm{Ibid}$.

${ }^{69}$ Compare ibid., and 2011/12:SoU18.

${ }^{70}$ A. Jonsson, 'EU:s lagstiftningsprocess och subsidiaritetsprövningen: Nya möjligheter för nationellt inflytande?', 4 SVJT (2011) p. 413 at p. 427. See also C. F. Bergström, 'Subsidiaritetsprövningen: riksdagen hittar en ny roll i EU:s lagstiftningsprocess', 3 ERT (2010) p. 423.

\footnotetext{
${ }^{71}$ Hettne, supra n. 36, p. 48.
} 
the Committee calls for an assessment as to what extent it is 'possible' to achieve the goals on a national level. In contrast, the test suggested by Hettne et al. is based on the wording of the Treaties and calls for a first step which asks whether the goal can be 'sufficiently' achieved at the national law. ${ }^{72}$ In the test suggested by the Committee, if the answer to the 'possible' question is yes, a second question is to be asked, namely if the goal can be 'better' achieved at the EU level. If the answer to this question is yes, there is no violation of the principle of subsidiarity. More importantly, if the answer to the first 'possible' question is no, the test recommended by the Committee provides that measures at the EU level are legitimate. It does not require that the second 'better' question is asked, a model which Hettne et al. strongly advocates against. ${ }^{73}$ Hettne et al. argues that the main purpose of the principle of subsidiarity is to promote or guard decentralisation. Therefore they suggest a test based on the 'sufficiency' and 'better' criteria. Moreover, if the answer to the first question is yes, they suggest that measures on the EU level will constitute a violation of the principle of subsidiarity. They also recommend that if the answer to the first 'sufficiency' question is no, the second question still needs to be asked, i.e. whether the goal is 'better' achieved at the EU level. If the answer to the second question is also no, any measure would cause a violation of the principle of subsidiarity. ${ }^{74}$ Due to the methodological lacunae in the yearly review made by the Committee on the Constitution, it is hard to tell what test the committees are actually applying. The Committee has stated repeatedly that it will not review the subsidiarity assessment made by the sectoral committees, a fact which could be said to explain why the Committee on the Constitution is reluctant to analyse and draw conclusions concerning the methods applied by the sectoral committees.

One of the main methodological concerns raised by the Committee on the Constitution in the 2014 report relates to the question whether scrutiny of the principle of subsidiarity should include a proportionality test. The Committee has declared that there is no such obligation, but that there is support in the doctrine and case law for including a limited proportionality test. ${ }^{75}$ In more than half of the reasoned opinions from 2012 the principle of proportionality was referred to. ${ }^{76}$ The Committee on Transport and Communications claims that the Government does not include proportionality in their subsidiarity test, which, according to the Committee causes a problem since the committees do include it. ${ }^{77}$ As a response to the question 'Can a subsidiarity review include an assessment of

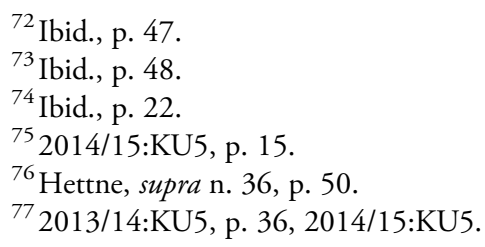


proportionality?' the Committee on the Constitution noted that no such obligation could be read from the Treaties and its protocols. However, it also found that this very fact did not allow for an $e$ contratio interpretation that it would not be allowed to do so. The Committee found that there was support for the subsidiarity review to include an assessment of the proportionality of the proposal based on the wording of Article 5(3) TEU ' ... the Union shall act only if and in so far as.... In order to avoid any misunderstanding it underlines that assessing proportionality in this context only involves the question at what level the measure should be taken: regional, national or EU. ${ }^{78}$ To give an example, the Committee on Transport and Communications drafted a reasoned opinion concerning a proposal on the internal market for electronic communication services. It stated that the proposal did not violate the principle of subsidiarity strictu senso, but that it violated the principle of proportionality within the principle of subsidiarity. The Riksdag argued that the Commission should enforce the existing regulatory framework, mainly directives, instead of adopting an overreaching regulation. Hence, this case could be added to the group of reasoned opinions by the Riksdag criticising the means of regulation chosen. ${ }^{79}$ By choosing regulations instead of directives when uncalled for according to the Swedish Riksdag, the EU violates the principle of subsidiarity, including proportionality. Thus, a proportionality test within the scrutiny of subsidiarity is allowed as long as it does not focus on whether the measure should be taken at all or not. It should focus solely on the level at which the measure should be decided and the form of legislative act to be adopted, either a directive or regulation. This scrutiny would fall under what Kiiver has called a proportionality test, where the intactness of the member states' competence is the potential victim.

Hettne et al. did put forward recommendations as how to frame a proportionality argument within the subsidiarity scrutiny. ${ }^{80}$ In the 2013 report the Committee on Traffic and Communications, again, pointed out difficulties related to the proportionality test. To be more specific, the Committee claimed that the fact that the committees do apply the principle of proportionality within the subsidiarity scrutiny, while the Government does not, poses a methodological challenge. ${ }^{81}$ More concretely, this has led to the Committee on Traffic and Communications and the Government reaching different conclusions as to a violation of the principle of subsidiarity in at least two cases. ${ }^{82}$ This is just one of

\footnotetext{
${ }^{78}$ The Committee relied on ECJ, 10 December, C-491-01, Brittish American Tobacco (Investments) Ltd v Imperial Tobacco Ltd, paras. 122-141, 180-185, and J. Hettne, Subsidiaritetsprincipen: Politisk granskning eller juridisk kontroll? [The principle of subsidiarity: Political scrutiny or judicial control?] (SIEPS 2003).

${ }^{79}$ 2013/14:TU5.

${ }^{80}$ 2014/15:KU5, p. 15. See also Hettne, supra n. 36, p. 27, 52-53.

${ }^{81}$ 2014/15:KU5, p. 39.

${ }^{82} 2014 / 15:$ TU1y.
} 
the methodological aspects that the Committee on the Constitution could adopt as a starting point when monitoring and evaluating scrutiny tests by sectoral committees.

\section{Scrutiny by sectoral committees and reasoned opinions}

During 2012 a total number of 125 subsidiarity reviews ${ }^{83}$ were conducted by the Riksdag, out of which 20 resulted in reasoned opinions. The Committee on Environment and Agriculture conducted most reviews (28), followed by the Committee on Finance (21). Until 2013, all of the 15 committees had made at least one subsidiarity review. The main difference between 2011 and 2012, besides the $100 \%$ increase in reasoned opinions, is that the number of reviews made by the Committee on Finance, the Committee on Foreign Affairs and the Committee on Social Insurance increased significantly. ${ }^{84}$ As a result of the reviews made by the committees, 20 draft reasoned opinions were submitted to the Chamber, all of them resulting in reasoned opinions. The figures for 2011 were 12 drafts and 10 reasoned opinions. In 2012, the review by the Committee on Finance resulted in seven reasoned opinions and the Committee on Justice produced three. The Committee on Environment and Agriculture, which made 28 reviews, only submitted one draft reasoned opinion to the Chamber. ${ }^{85}$ Reservations can be made by the Committee members to the opinion of the majority, which happened in seven cases in 2012. In one of these, concerning Eurosur, the Chamber decided in favour of the minority opinion. ${ }^{86}$ Both the majority and the minority found the proposal to be in violation of the principle of subsidiarity. The minority opinion was, however, more articulate and detailed, and hence sharper in its formulation.

During 2013, 123 subsidiarity reviews were conducted by the sectoral committees in the Riksdag, rendering 10 reasoned opinions. ${ }^{87}$ The Committee on Transport and Communications reviewed 27 drafts which resulted in four reasoned opinions. Apart from the Committee on Transport and Communications, the Committees on Justice, Finance, Taxation, Social Insurance, Defence, and the Committee on Environment and Agriculture produced one reasoned opinion each. The Committees on Justice, Transport and Communication, Environment and Agriculture, and Finance have each reviewed more than 10 drafts during $2013 .^{88}$ The main difference

${ }^{83}$ 2013/14:KU5, p. 16. For a complete list of topics see, bilaga [appendix] 12. The number for 2011 was 124.

${ }^{84}$ 2013/14:KU5, p. 16-18. 2009-2010 71 proposals were reviewed and three reasoned opinions adopted by the Chamber.

${ }^{85}$ Ibid., p. 17.

${ }^{86}$ 2011/12:JuU29, Riksdagsskrivelse 2011/12:156.

${ }^{87} 2014 / 15:$ KU5, p. 21.

${ }^{88} \mathrm{Ibid}$. 
between 2012 and 2013 is the decline in the number of reasoned opinions from 20 in 2012 to 10 in 2013, the number of legislative acts more or less being the same (125/123). The committee submitting the most reasoned opinions between 2010 and 2013 was the Committee on Finance (12), while the Committee on Environment and Agriculture reviewed the highest number of drafts (95) during the same time period, resulting in five reasoned opinions altogether. The Committee of Finance and the Committee on Transport and Communications reviewed 62 drafts each between 2010 and 2013. The Committee on Transport and Communications has submitted five reasoned opinions, as has the Committee on Justice (out of 44 reviewed drafts) during the same time period. ${ }^{89}$ The number of reasoned opinions submitted by the Riksdag in 2014 dropped significantly again, from 10 in 2013 to two in 2014..$^{90}$

An analysis of the reasoned opinions submitted by the Riksdag up to 2014 shows that the committees do not strictly adhere to the subsidiarity test recommended by the Committee on the Constitution. Rather, they are more free in their approach and do consider other aspects than those strictly referable to the principle of subsidiarity. Questions related to such areas as competence, legal basis and the substance of the proposals are dealt with. This conclusion confirms the trend from early years. ${ }^{91}$ One particular case stands out and will therefore be dealt with in more detail. This is the legislative draft on the European Public Prosecutor's Office.

\section{The European Public Prosecutor: a case in point}

On 6 November 2013 the Commission confirmed that Article 7(2) Protocol No 2 had been triggered concerning the European Public Prosecutor's Office draft, meaning that the proposal had to be reviewed. Subsequent to responding to the reasoned opinions by national parliaments the Commission decided to maintain its proposal. ${ }^{92}$ In its reasoned opinion on the European Public Prosecutor's Office the Swedish Riksdag declared that the proposal in its totality was in violation of the principle of subsidiarity. ${ }^{93}$ The Committee on Justice started out by referring to the Political Dialogue and the concerns that the Riksdag had already put forward in that context. Thereafter the Committee expressed fear that the establishment of the European Public Prosecutor's Office would have far-reaching consequences

${ }^{89} \mathrm{Ibid}$.

${ }^{90}$ 2015/16:KU5, p. 20.

${ }^{91}$ See Hettne, supra n. 36, p. 49.

${ }^{92} \operatorname{COM}(2013) 851$ final.

${ }^{93}$ 2013/14:JuU13. The Committee on Justice had voiced its opinion concerning this regulation already at the initial stage of the Political Dialogue process, i.e. when the Commission presented its 2013 work program. See 2012/13:JuU2y. 
for Swedish legislation and Swedish authorities. It also expressed concern that the powers of European Public Prosecutor's Office could be expanded according to Article 86 TFEU. It was therefore, the argument went, difficult to oversee the long-term consequences of the proposal. The Committee also drew attention to the fact that the Government had not delivered its assessment on subsidiarity on this proposal. ${ }^{94}$ The Committee thereafter stated that the Commission had failed to show why the goal could not be achieved by the member states cooperating within the framework of Eurojust. Moreover, the Commission had failed to convince the Committee that this goal would be better achieved by EU measures. And finally, it drew the conclusion that the measure failed the proportionality test. ${ }^{95}$ This is where the reasoned opinion becomes interesting from an analytical point of view. I would argue that the Committee made a two-tier proportionality test. First, the Committee concluded that it must be considered disproportional to regulate at the EU level just because some member states were unable to uphold the desired standards concerning investigations and prosecutions of crimes against economic interests of the EU. This should be considered a proportionality test within the subsidiarity review, as understood in the Swedish context. Clearly, its purpose is to determine at what level - national or EU - the regulation should take place. The Committee then proceeded to a proportionality argument that could be considered to go beyond a limited proportionality test within the subsidiarity review. In this line of argument the Committee argued that the draft went too far and that it exceeded what was necessary to achieve the overall goal, i.e. to protect the economic interest of the EU. ${ }^{96}$ This part of the reasoned opinion addressed the substance of the proposal in a way that is not clearly referable to subsidiarity.

There are several problems with this particular reasoned opinion. First, it mixes different procedures for how national parliaments comment on EU legislative drafts. Second, it refers to the legal basis in the TFEU pinpointing that it might lead to broader powers in the future without making clear how this relates to subsidiarity. And thirdly, its proportionality argument is too broad. That being said, it could be argued that the Riksdag applied the scrutiny mechanism in this particular case for the purpose of safeguarding the member states' competence and upholding decentralisation. In so doing it added a time factor into the analysis. It underlined that several measures already adopted by the EU had not been allowed to settle themselves yet, and that possibilities for cooperation within the Eurojust had not been fully explored. Basically, it considered it premature to establish the European Public Prosecutor's Office since the effects of measures already in play had not been fully implemented yet and hence their full potential

\footnotetext{
${ }^{94}$ 2013/14:JuU13, p. 8.

${ }^{95}$ Ibid.

${ }^{96}$ Ibid., p. 9.
} 
could not yet be analysed or evaluated. One could also argue that the Swedish Riksdag asked the Commission to exercise legislative restraint. It did not question the existence of EU powers, simply the extent to which they were exercised at this particular moment in time.

The Commission dismissed the Riksdag's assessment of the proposal for being too far-reaching, and for going beyond what was necessary for reviewing subsidiarity, and hence falling outside the scope of the scrutiny of the principle of subsidiarity. As a result, the Commission decided to address some of these questions within the Political Dialogue. ${ }^{97}$

In conclusion, this case shows that there is an underused potential for the Committee on the Constitution to advice sectoral committees on how to conduct and especially formulate a reasoned opinion. The Committee on Transport and Communications has explicitly asked for concrete guidelines from the Committee on the Constitution as to what criteria should be considered in the scrutiny process. It has also expressed a desire for a unitary approach to the scrutiny process and what it should include. ${ }^{98}$

\section{Evaluating the role of the Committee on the Constitution}

In the following section an evaluation of the yearly reports of the Committee on the Constitution will be made taking the legislator's (lack of) intent as regards this issue as starting point. First we must conclude that the legislator did not really elaborate on its intent, leaving it to the Committee on the Constitution to define its role and task. ${ }^{99}$ Thus, the task that the Committee has defined for itself is to compile data on the formal procedure of scrutiny, assess the impact of the scrutiny on the EU legislative procedure, and guard the delimitation of EU competences. It is noteworthy that the analysis of the formal aspects, including method, made by the Committee stretches over two pages, of which the first is merely a summary of the policy areas within which reviews are made and an account of statistics. ${ }^{100}$ The absence of an analysis is striking; the Committee, to use its own words, merely makes some reflections. These reflections are, however, little but a summary of the statements made by the sectoral committees. My conclusion is that this must be seen as the result of the Committee on the Constitution's firm conviction that the Committee must not review the scrutiny made by the sectoral committees. ${ }^{101}$ Thus, the question is whether this is a matter of constitutional prudency or a question of method. Is it impossible for the Committee to be analytical without

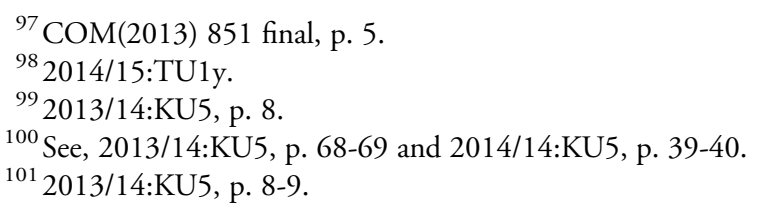


reviewing and evaluating the scrutiny made by the sectoral committees? As it stands currently, the Committee is basically providing a compiled overview of the activities of the sectoral committees together within statistics. The absence of analysis and guidance as to method is striking and contradictionay to the ambition of the Committee as put forward in earlier reports.

The choice of method and approach adopted by the Committee on the Constitution bring with it several consequences. First, sectoral committees are expected to turn to the Committee for guidance in how to scrutinise the principle of subsidiarity from a methodological point of view. In the 2012 report some committees asked for guidance from the Committee on the Constitution in order for the scrutiny to be equal between the different committees. In its reply, the Committee referred to the two-step method described above. ${ }^{102}$ In the 2011 report the Committee concluded that the two-step method worked fine, although the Committee could not be sure that it was applied by all the committees, or that it was applied in a similar manner. The Committee stated that the method should be considered a guideline. ${ }^{103}$ This, in combination with the fact that the Committee clearly stated in its 2013 report that it will not make any systematic analysis concerning the method applied by the committees when scrutinising, means that the Committee potentially will have difficulties guiding towards a unitary applied method. It could be that neither the Committee on the Constitution, nor the sectoral committees find this necessary or even desirable anymore, and that it leaves room for a flexibility which could be desirable in political processes. However, from a methodological point of view this is unsatisfying and there might be consequences both for the Riksdag's cooperation with other parliaments and a potential future legal procedure should a case be initiated before the European Court of Justice.

As has been stated above, in its latest report the Committee emphasised that reasoned opinions must be clear as to the principle of subsidiarity, which was not the case in the Swedish reasoned opinion on the European Public Prosecutor's Office. I would argue that this could have been avoided had the Committee on the Constitution taken its task to guide on method more seriously. The guidelines provided by the Committee are based primarily on what has been stated in the travaux preparatiore. ${ }^{104}$ There has not been, to my knowledge, any updated analysis taking the five years of practice into consideration. The Committee has stated that it will develop its method for the yearly report subsequently, since the

${ }^{102}$ 2012/13:KU8, p. 1, 30. The Committee also repeated the possibility for committees to ask the Committee for guidance concerning interpretation and method, while also stating that the yearly reports are supposed to function as a support for sectoral committees.

${ }^{103}$ 2011/12:KU4, p. 23.

${ }^{104}$ For an illustration see, for example, 2013/14:KU5, p. 12-15. 
travaux preparatoire do not provide guidance in this particular aspect. ${ }^{105}$ However, the lack of a qualitative method applied by the Committee will make this task difficult. By not analysing how the sectoral conduct their review besides describing it, it will be difficult for the Committee to provide guidance as to both the procedural and material aspects of the principle of subsidiarity.

\section{Conclusions}

Taking its starting point in different theoretical understandings of the scope of the review of the principle of subsidiarity, a case study of Sweden allows for the conclusion that the Swedish Riksdag practises a broad scope of the review. It is close to Cooper's Political Arguing approach. The Swedish definition and understanding of the principle of subsidiarity is vague but certainly not meaningless, political aspects and arguments are taken into consideration, but there is no overemphasis on political expediency. The scope of the review of subsidiarity exercised by the Riksdag also confirms Kiiver's and Jančićs understanding of the scope of the review. The Riksdag can, and sometimes does, take its starting point in the principle of conferral. It is, according to the Swedish travaux preparatoire, allowed to make a limited proportionality test and political arguments such as taking the elapsed time into consideration is made. Thus, one could argue that the Riksdag makes political arguments within the scrutiny in the sense that it asks the Commission to show legislative restraint, as in for example the reasoned opinion on European Public Prosecutor's Office. Another conclusion is that the narrow understanding of the principle of subsidiarity suggested by Fabbrini and Granat is simply not preferred nor applied by the Riksdag.

The Swedish Riksdag perceives the scrutiny of subsidiarity primarily as a tool for safeguarding decentralisation and for keeping itself updated of any competence overstretches on behalf of the EU legislator. The Committee on the Constitution has been allowed to carve out its role in the national scrutiny process. It is clear that the Committee on the Constitution mainly considers itself as a gatekeeper whose main task is to identify any competence overstretch on behalf of the EU legislator within the area of shared competence between the EU and its member states, primarily by compiling the analysis made by sectoral committees. The sectoral committees have asked the Committee to be more proactive when it comes to advising on methods for the scrutiny, identify common criteria etc. This is a role with the Committee has been reluctant to take. An analysis of the reasoned opinions submitted by the Swedish Riksdag leads to the conclusion that such guidelines are needed and that there is a potential to develop the subsidiarity reasoning and hence make the Swedish reasoned opinions potentially more

${ }^{105}$ 2013/14:KU5, p. 8, 2011/12:KU4, p. 35. 
influential, the starting point being that the more clear, structured and to the point a reasoned opinion is, the harder it will be for the Commission to disregard it without a sincere and thorough motivation.

As has been described above, the scrutiny is a difficult task for national parliaments. They tend to stray away from its main purpose and regulatory framework. Sweden is not alone in this. It is a general problem that reasoned opinions are vague and broad. ${ }^{106}$ However, I argue that this is not in itself reason enough to write off the Early Warning Mechanism per se, nor to stretch it so that it becomes too close to the Political Dialogue. Rather, it should direct the attention to methodological issues and proceed to identify who has the responsibility for defining and upholding methodological standards as to the scrutiny within the national context. The misinterpretation and overstretching in the use of the Early Warning Mechanism by national parliaments do not per se disqualify the tool. Rather, it should lead to a sharpening of the procedure, both on behalf of national parliaments and the Commission. It has been argued that the scrutiny risks diverting national parliaments' attention away from their main task. I simply do not agree. National parliaments can, and are expected to, fulfil several tasks simultaneously. Moreover, national parliaments did confer powers on the $\mathrm{EU}$; why should national parliaments then not be involved in upholding the boundaries of the exercising of EU powers? It is not a question of if they should or not, it is a question of how. The main purpose of the Early Warning Mechanism is not to affect policy, it should not be impossible for national parliaments to adjust to this even though their expertise is within policy making. The Early Warning Mechanism is not the only game in town. It is certainly not the best game in town. Nevertheless, for the time being this is the game that national parliaments are stuck with. Therefore a starting point to be recommended would be to excel at the game according to the applicable rules, and stretch those rules to the benefit of the players - in this context the national parliaments. Sweden could take the lead and the Committee on the Constitution could play an important role in that process. Whether it will do so remains to be seen.

\footnotetext{
${ }^{106} \mathrm{~K}$. Granat, National parliaments and the policing of the subsidiarity principle (European University Institute 2014). See also Jančić, supra n. 1, p. 948.
} 